\title{
Changes in GSH-antioxidant system induced by daunorubicin in human normal and diabetic fibroblasts
}

\author{
Agnieszka Zatorska ${ }^{1}$, Janusz Maszewski ${ }^{2}$ and Zofia Jóźwiak ${ }^{1 凶}$ \\ ${ }^{1}$ Department of Thermobiology, and ${ }^{2}$ Department of Cytophysiology, University of Eódż, Poland
}

Received: 03 April, 2003; revised: 07 July, 2003; accepted: 02 September, 2003

Key words: glutathione, daunorubicin, glutathione peroxidase, glutathione reductase, glutathione $S$-transferase, apoptosis, oxidative stress

\begin{abstract}
We investigated the effect of daunorubicin on glutathione content and activity of GSH-related enzymes in cultured normal and diabetic human fibroblasts. Cells were incubated with $4 \mu \mathrm{M}$ daunorubicin (DNR) for $2 \mathrm{~h}$ followed by culture in drug-free medium for up to $72 \mathrm{~h}$. Treatment of diabetic cells with the drug caused a time-dependent depletion of intracellular GSH and a decrease of the GSH to total glutathione ratio. GSH depletion was accompanied by apoptotic changes in morphology of the nucleus. Analysis of GSH-related enzymes showed a significant increase of the activities of Se-dependent and Se-independent peroxidases and glutathione $S$-transferase. In contrast, glutathione reductase activity was reduced by $\mathbf{5 0} \%$. Significant differences between normal and diabetic cells exposed to DNR were observed in the level of GST and Se-dependent glutathione peroxidase activities.

These findings indicated that daunorubicin efficiently affects the GSH antioxidant defense system both in normal and diabetic fibroblasts leading to disturbances in glutathione content as well as in the activity of GSH-related enzymes.
\end{abstract}

The anthracycline antibiotic daunorubicin is still one of the most frequently used antitumor agents in clinical oncology. Anthracycline cytotoxicity is generally believed to be the result of intercalation-induced DNA damage and stabilization of the cleavable complex formed between DNA and topoisomerase II (Meyers et al., 1988; Gewirtz, 1999). Moreover, daunorubicin metabolizes to form reactive oxygen species (ROS), superoxide anion radical, hydroxyl free radical and hydrogen peroxide, which interact with cell membranes,

${ }^{凶}$ Address correspondence to: Zofia Jóźwiak, Department of Thermobiology, University of Łódź, S. Banacha 12/16, 90-237 Łódź, Poland; fax: (48 42) 635 4473; e-mail: zjozwiak@biol.uni.lodz.pl Abbreviations: DNR, daunorubicin; GPX, glutathione peroxidase; GR, glutathione reductase; GSH, reduced glutathione; GSSG, oxidized glutathione; GST, glutathione $S$-transferase; MTT, 3-(4,5-dimethylthiazol-2-yl)-2,5-diphenyl tetrazolium bromide; PBS, sodium phosphate buffered saline; ROS, reactive oxygen species. 
proteins and DNA (Powis, 1989; O'Brien, 1991). An increase of intracellular concentration of ROS is tightly regulated by multiple defense mechanisms involving ROS scavenging enzymes and small antioxidant molecules. Among these antioxidant systems acting as antioxidants or scavengers are glutathione (GSH) and GSH-dependent enzymes (Sies, 1999; Cnubben et al., 2001). Glutathione, the main intracellular thiol antioxidant, participates in a number of cellular antitoxic and defensive functions. It restores damaged molecules by hydrogen donation, reduces $\mathrm{H}_{2} \mathrm{O}_{2}$ and lipid peroxides and plays an important role in drug detoxification (Sies, 1999; Griffith, 1999). Recent studies have demonstrated the role of GSH in regulation of gene expression and apoptosis (Hammond et al., 2001).

GSH constitutes more than $95 \%$ of total intracellular glutathione (GSH + GSSG) (Wernerman et al., 1999). GSH depletion has been identified in the pathogenesis of a variety of diseases as well as in drug-treated cells (Samiec et al., 1998; Paranka \& Dorr, 1994). Furthermore, a decrease of the GSH/GSSG ratio is considered as an early indicator of oxidative stress.

Although considerable progress has been made, the precise role of the GSH-dependent antioxidant system in protection of cells from drug-induced oxidative damage is still poorly understood. The aim of this study was to obtain further insights into the role of endogenous glutathione in drug-treated cells. Because changes in glutathione content are involved in the pathogenesis of many diseases, including diabetes, we decided to analyze the levels of GSH and GSH-related enzymes in cultured diabetic human fibroblasts exposed to oxidative stress. Diabetic cell lines were subjected to daunorubicin treatment and changes in the levels of GSH and the enzymes were estimated spectrophotometrically. We also investigated the effect of the drug-induced GSH depletion on the induction of apoptosis in the cells.

\section{MATERIALS AND METHODS}

Materials. Daunorubicin was obtained from Laboratoire Roger Bellon (France). Eagle's Minimal Essential Medium was from the Sera and Vaccines Factory (Lublin, Poland), calf serum and lactalbumin hydrolysate were from Gibco BRL (Scotland). Gentamicin was purchased from Biochemie Gesellschaft m.b.H (Vienna, Austria). All other chemicals and solvents were of high analytical grade and were obtained from commercial sources.

Cell culture. C-2 and C-5 are cell lines derived from the skin of diabetic patients type II, and S-126 cell line from the skin of a normal donor. They were obtained from the tissue bank of the Centre of Child Health (Warsaw, Poland). Cells were cultured as monolayers in Eagle's Minimal Essential Medium supplemented with $10 \%$ newborn calf serum, $10 \%$ lactalbumin hydrolysate and $5 \mu \mathrm{g} / \mathrm{ml}$ gentamicin. Fibroblasts were maintained at $37^{\circ} \mathrm{C}$ in a humidified atmosphere containing $5 \% \mathrm{CO}_{2}$. For the experiments, cells between 5 th and 15 th passage were used. Under the culture conditions we have observed no differences in the growth properties of the normal and diabetic cell lines.

Drug treatment. Solutions of daunorubicin in PBS (sodium phosphate buffered saline), stored as small aliquots at $-20^{\circ} \mathrm{C}$, were thawed immediately prior to use. The cells were incubated with $4 \mu \mathrm{M}$ daunorubicin at $37^{\circ} \mathrm{C}$ for $2 \mathrm{~h}$. After incubation, cells were rinsed twice with cold PBS to remove free drug. Then fresh medium was added and the cells were cultured at $37^{\circ} \mathrm{C}$ for further $6-72 \mathrm{~h}$.

Cytotoxicity assays. Cytotoxicity was measured using the colorimetric MTT assay as described previously (Przybylska et al., 2001). Briefly, fibroblasts were plated at $1 \times 10^{4}$ cells/well per $200 \mu \mathrm{l}$ in 96-well microtiter plates. DNR was added at a concentration of $1-15 \mu \mathrm{M}$ and incubated at $37^{\circ} \mathrm{C}$ for $2 \mathrm{~h}$. The medium was removed, replaced with drug-free medium, and plates were incubated for a fur- 
ther $72 \mathrm{~h}$. Then MTT was added and incubation was continued for a further $4 \mathrm{~h}$. After aspiration of the culture medium, the resulting formazan crystals were dissolved in dimethyl sulfoxide and absorbance was immediately read at $570 \mathrm{~nm}$. The fraction of surviving cells was determined by dividing the mean absorbance values of the drug-treated samples by the mean absorbance value of the untreated control. The $\mathrm{IC}_{50}$ parameter is the DNR concentration that reduces the absorbance value to $50 \%$ of the value in control cells.

Measurement of enzyme activities. Cells plated in dishes were rinsed twice with cold PBS, scraped and lysed in 1\% Triton X-100, $0.25 \mathrm{M}$ sucrose and $10 \mathrm{mM}$ Tris/ $\mathrm{HCl}, \mathrm{pH} 7.4$ and centrifuged at $1000 \times \mathrm{g}$ for $5 \mathrm{~min}$ at $4^{\circ} \mathrm{C}$. The supernatants were used for enzyme activity assays.

Glutathione reductase (GR) activity. Activity of the enzyme was determined as described by Calberg \& Mannervik (1975). The reaction mixture consisted of $0.1 \mathrm{M}$ phosphate buffer, $\mathrm{pH}$ 7.6, containing $0.5 \mathrm{mM}$ EDTA, $1.0 \mathrm{mM}$ GSSG, $0.1 \mathrm{mM}$ NADPH and $100 \mu \mathrm{l}$ aliquots of the supernatant in a final volume of $1.0 \mathrm{ml}$. The consumption of NADPH was monitored spectrophotometrically at 340 $\mathrm{nm}$. The enzyme activity was expressed as nmol of NAPDH oxidized per min per milligram of protein, using an extinction coefficient of $6.22 \mathrm{mM}^{-1} \mathrm{~cm}^{-1}$.

GSH-peroxidase (GPX) activity. This was also measured at $340 \mathrm{~nm}$ by the glutathione reductase-coupled method reported by RiceEvans et al. (1991). The reaction mixture for the measurement of enzyme activity contained the following constituents at the final concentrations indicated: $0.05 \mathrm{M}$ phosphate buffer, pH 7.0, $0.1 \mathrm{mM}$ EDTA, $0.15 \mathrm{mM}$ $\mathrm{NADPH}, 240 \mathrm{U} / \mathrm{ml}$ GSH reductase, $1.0 \mathrm{mM}$ GSH and $100 \mu \mathrm{l}$ aliquots of the supernatants. In addition, the substrates $0.12 \mathrm{mM}$ tert-butyl hydroperoxide, to quantify total (Se-dependent and Se-independent) GSH-peroxidase activity or $0.015 \mathrm{mM}$ hydrogen peroxide for Se-dependent peroxidase activity were added to the reaction mixture. When $\mathrm{H}_{2} \mathrm{O}_{2}$ was used as a substrate, $1 \mathrm{mM}$ sodium azide was added to the reaction mixture to inhibit catalase activity. The activity of Se-independent glutathione peroxidase was calculated as the difference between the activity of total and Se-dependent peroxidase. The enzyme activity was expressed as above glutathione reductase.

Glutathione S-transferase (GST) activity. This was assayed by measuring at $340 \mathrm{~nm}$ the rate of formation of a GSH conjugate with 1-chloro-2,4-dinitrobenzene (CDNB) (Rice-Evans et al., 1991). The reaction mixture contained $100 \mu \mathrm{l}$ aliquots of the supernatant, 1.0 mM GSH, 1.0 mM CDNB and 0.1 M phosphate buffer, $\mathrm{pH} 6.5$, in a final volume of $1.0 \mathrm{ml}$. A milimolar extinction coefficient of 9.6 was used to calculate the enzyme activity. The activity was expressed in $\mathrm{nmol} / \mathrm{min}$ per $\mathrm{mg}$ of protein.

Glutathione measurement. Control cells and cells after incubation with the drug were mixed with $2 \mathrm{M}$ perchloric acid and $4 \mathrm{mM}$ EDTA solution and centrifuged $5 \mathrm{~min}$ at 5000 $\times$ g. The supernatant was neutralized with $2 \mathrm{M} \mathrm{KOH}$ in $0.3 \mathrm{Mops}$ solution, centrifuged and assayed for GSH and total glutathione as described by Akerboom \& Sies (1981). GSH content in the supernatant was determined by reaction with o-phtaldialdehyde. Total glutathione (the sum of GSH and GSSG) was determined in the supernatant by a kinetic assay in which catalytic amounts of GSH or GSSG and glutathione reductase caused a continuous reduction of 5,5'-dithiobis-2-nitrobenzoic acid (DTNB) by NADPH. The rate of DTNB reduction was measured spectophotometrically at $412 \mathrm{~nm}$. GSH and total glutathione were expressed in $\mathrm{nmol} / \mathrm{mg}$ protein.

Apoptosis. Apoptosis was assessed by fluorescence microscopy. After $2 \mathrm{~h}$ exposure to daunorubicin cells were washed with PBS and incubated in drug-free medium for 24, 48 and $72 \mathrm{~h}$. Cells were then stained with Hoechst $33342(10 \mu \mathrm{g} / \mathrm{ml})$ for $1 \mathrm{~h}$ at $37^{\circ} \mathrm{C}$ and analyzed for nuclear morphology changes on an Olympus fluorescence microscope. 
Protein measurement. Protein content was measured by the method of Lowry et al. (1951) using bovine serum albumin as a standard.

Statistical analysis. Statistical significance was assessed by Student's $t$-test and $P<$ $0.05\left(^{*}\right)$ and $P<0.01\left(^{* *}\right)$ were considered to be statistically significant. Data are given as mean \pm S.D. for five to eight separate experiments.

\section{RESULTS}

\section{Glutathione and GSH-dependent enzymes in control fibroblasts}

The level of total and reduced glutathione and the activity of GSH-related enzymes in diabetic and normal cultured cell lines are shown in Table 1 . There were no significant differences in the levels of glutathione and glutathione reductase (GR) between the examined cells. Significant changes were observed respectively, in comparison with the normal cell line (S-126).

\section{Cytotoxicity assays}

The responses of fibroblasts to DNR treatment were analyzed by drug cytotoxicity, the level of glutathione and GSH-dependent enzymes and by fluorescence microscopy. The cells were exposed to $4 \mu \mathrm{M}$ daunorubicin for

Table 2. Values of $\mathrm{IC}_{50}$ in human fibroblast lines after daunorubicin treatment

\begin{tabular}{lrrr}
\hline Cell line & Origin & Karyotype & $\mathrm{IC}_{50}$ \\
\hline Control cells & & & \\
S-126 & skin & $46, \mathrm{XY}$ & $4.3 \pm 0.1 \mu \mathrm{M}$ \\
Diabetic cells & & & \\
C-2 & skin & $46, \mathrm{XY}$ & $10.2 \pm 0.5 \mu \mathrm{M}$ \\
C-5 & skin & $46, \mathrm{XX}$ & $9.7 \pm 0.6 \mu \mathrm{M}$ \\
\hline
\end{tabular}

Table 1. Levels of glutathione and GSH-dependent enzymes in normal and diabetic fibroblasts.

Mean \pm S.D. of $5-8$ determinations $\left({ }^{*} P<0.05\right)$.

\begin{tabular}{lccc}
\hline & $\begin{array}{c}\text { Normal } \\
\text { fibroblasts }\end{array}$ & \multicolumn{2}{c}{ Diabetic fibroblasts } \\
\cline { 2 - 4 } & $\mathrm{S}-126$ & $\mathrm{C}-2$ & $\mathrm{C}-5$ \\
\hline Total glutathione (nmol/mg protein) & $17.0 \pm 2.5$ & $16.9 \pm 0.6$ & $16.9 \pm 1.0$ \\
GSH (nmol/mg protein) & $16.3 \pm 1.3$ & $15.1 \pm 0.1$ & $15.0 \pm 1.0$ \\
Total glutathione peroxidase (nmol/min/mg protein) & $18.0 \pm 1.5$ & $24.1 \pm 2.0^{*}$ & $26.0 \pm 1.9^{*}$ \\
Glutathione reductase (nmol/min/mg protein) & $6.2 \pm 0.8$ & $6.2 \pm 0.5$ & $5.3 \pm 0.5$ \\
Glutathione S-transferase (nmol/min/mg protein) & $11.9 \pm 1.2$ & $9.0 \pm 0.5^{*}$ & $9.5 \pm 0.7$ \\
\hline
\end{tabular}

in total glutathione peroxidase $\left(\mathrm{GPX}_{\mathrm{x}}\right)$ and glutathione $S$-transferase (GST) activities. In the diabetic cell lines (C-2 and C-5) the activity of $\mathrm{GPX}_{\mathrm{x}}$ was enhanced by $34 \%$ and $44 \%$, and GST levels were decreased by $32 \%$ and $26 \%$,
$2 \mathrm{~h}$ and then cultured in drug-free medium for up to $72 \mathrm{~h}$. As shown in Table 2 the $\mathrm{IC}_{50}$ values for DNR were $10.2 \mu \mathrm{M}$ and $9.7 \mu \mathrm{M}$ for the C-2 and C-5 cell lines and $4.3 \mu \mathrm{M}$ for the normal cells, respectively. The diabetic cells were thus 
Table 3. The effect of DNR on GSH and total glutathione contents in diabetic (lines C-2 and C-5) and normal (line S-126) fibroblasts.

Values are mean \pm S.D. for eight to ten separate experiments. Values significantly different from the respective controls at time zero are indicated $\left({ }^{*} P<0.05\right.$ and $\left.{ }^{* *} P<0.01\right)$.

\begin{tabular}{|c|c|c|c|c|c|c|c|c|c|}
\hline \multirow{2}{*}{$\begin{array}{c}\text { Time after } \\
\text { drug } \\
\text { treatment } \\
\text { (h) }\end{array}$} & \multicolumn{3}{|c|}{$\begin{array}{l}\text { Total glutathione } \\
\mathrm{nmol} / \mathrm{mg} \text { of protein }\end{array}$} & \multicolumn{3}{|c|}{$\begin{array}{c}\text { GSH } \\
\mathrm{nmol} / \mathrm{mg} \text { of protein }\end{array}$} & \multicolumn{3}{|c|}{$\mathrm{GSH} /$ total glutathione } \\
\hline & S-126 & $\mathrm{C}-2$ & C-5 & S-126 & C-2 & C-5 & S-126 & C-2 & C-5 \\
\hline 0 & $17.0 \pm 2.5$ & $16.9 \pm 0.6$ & $16.9 \pm 1.0$ & $16.3 \pm 1.3$ & $15.1 \pm 0.1$ & $15.0 \pm 1.0$ & 1.0 & 0.9 & 0.9 \\
\hline 6 & $15.6 \pm 2.6$ & $17.3 \pm 0.6$ & $17.3 \pm 1.1$ & $14.8 \pm 1.3$ & $14.2 \pm 0.3$ & $14.7 \pm 0.4$ & 1.0 & 0.8 & 0.9 \\
\hline 12 & $18.7 \pm 2.0$ & $18.5 \pm 1.0$ & $17.5 \pm 0.9$ & $14.1 \pm 1.5$ & $13.7 \pm 0.7^{*}$ & $14.0 \pm 1.1$ & 0.8 & 0.7 & 0.8 \\
\hline 24 & $20.1 \pm 1.3^{*}$ & $19.1 \pm 0.8^{*}$ & $19.4 \pm 0.8^{*}$ & $13.2 \pm 0.9^{*}$ & $13.3 \pm 0.5^{*}$ & $12.3 \pm 0.8^{*}$ & 0.7 & 0.7 & 0.6 \\
\hline 48 & $22.3 \pm 1.0^{*}$ & $18.0 \pm 0.6$ & $18.7 \pm 1.0$ & $12.0 \pm 1.1^{* *}$ & $12.1 \pm 0.7^{* *}$ & $11.5 \pm 0.6^{* *}$ & 0.5 & 0.7 & 0.6 \\
\hline 72 & $18.3 \pm 1.3$ & $17.2 \pm 1.1$ & $17.7 \pm 0.7$ & $11.3 \pm 1.0^{* *}$ & $11.0 \pm 0.5^{* *}$ & $10.6 \pm 0.9^{* *}$ & 0.6 & 0.6 & 0.6 \\
\hline
\end{tabular}

2-fold more resistant to the drug than the normal cell line S-126.

\section{Effect of DNR on glutathione content}

The changes in intracellular GSH and total glutathione content in drug-treated diabetic and normal cells are presented in Table 3 . Treatment of the cells with DNR exerted a time-dependent effect on the level of glutathione.

The concentration of total glutathione in both diabetic cell lines increased slowly with time of culture. The levels of total glutathione were elevated by $13-14 \%$ in drug-treated cells at 24-48 $\mathrm{h}$ compared to the respective controls at time 0 . At the same time a gradual decrease in the level of GSH was observed. The concentration of GSH was lowered by $27-30 \%$ after $72 \mathrm{~h}$ of drug exposure. Consequently, the ratio of GSH to total glutathione was decreased from 0.9 to 0.6 (mean values for both cell lines).

Treatment of normal fibroblasts (line S-126) with DNR caused a decrease in total glutathione level within the initial $6 \mathrm{~h}$ of incubation. Then the content of total glutathione markedly increased (to $118-131 \%$ of the control value) in the 24-48 h period. The level of $\mathrm{GSH}$ and the GSH/total glutathione ratio were lowered by $30 \%$ and $35 \%$, respectively, at $72 \mathrm{~h}$. These results indicate that the same concentration of DNR induced similar changes in GSH content in the diabetic and normal cells.

\section{Effect of DNR on the activity of GSH-associated enzymes}

Changes in the activity of GSH-related enzymes were also analyzed in the cells exposed for $2 \mathrm{~h}$ to $4 \mu \mathrm{M}$ DNR. The results are shown in Fig. 1-3. As illustrated in Fig. 1A, B, the drug exposure led to a significant increase in the total as well as Se-dependent and Se-independent glutathione peroxidase activities in the diabetic cell lines. The level of total GPX was elevated by $81 \%$ and $106 \%$ respectively, in DNR-treated diabetic cell lines C-2 and C-5 at $48 \mathrm{~h}$ compared to their respective controls (time 0). At the same time, the Se-dependent and Se-independent glutathione peroxidase activities increased by $84 \%$ and $139 \%$ (mean maximal increase for the C-2 and C-5 cell lines, respectively, at $48 \mathrm{~h}$ ). Figure $1 \mathrm{C}$ shows alterations in the activity of $\mathrm{GPX}_{\mathrm{X}}$ in the normal fibroblasts. In drug-treated cell line S-126 the maximal increase of total and Se-dependent glutathione peroxidase activities was observed at $72 \mathrm{~h}$ (respectively to $229 \%$ and $303 \%$ of the control values). The highest enhance- 
ment in the activity of Se-independent glutathione peroxidase was noted at $48 \mathrm{~h}$ ( $241 \%$ of control at time 0 ).

The activity of glutathione reductase in drugtreated cells was non-significantly changed
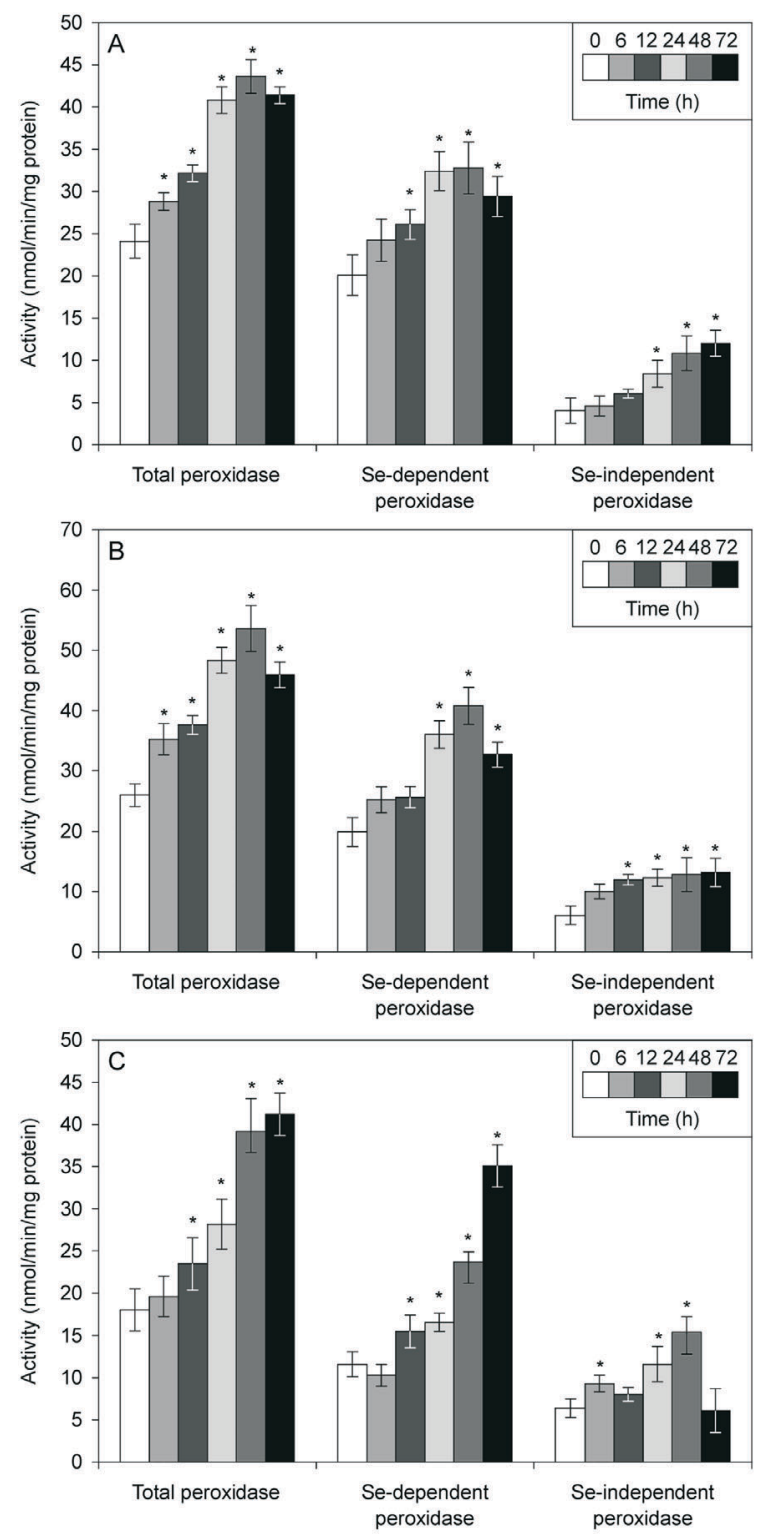

Figure 1. Effect of daunorubicin on total, Se-dependent and Se-independent glutathione peroxidase activity in C-2 (A), C-5 (B) and S-126 (C) fibroblasts.

Cells were incubated with $4 \mu \mathrm{M}$ DNR for $2 \mathrm{~h}$ followed by culture in drug-free medium for up to $72 \mathrm{~h}$. Data are shown as the mean \pm S.D. of six experiments. The asterisk $\left({ }^{*}\right)$ indicates a statistically significant difference from control (time zero for respective cells) by Student's $t$-test analysis $(P<0.05)$ during the first $24 \mathrm{~h}$ in the normal and $12 \mathrm{~h}$ in the diabetic cells (Fig. 2). During the incubation of the C-2 and C-5 cell lines for 24-72 h the enzyme activity decreased (mean depletion by $52 \%$ at $72 \mathrm{~h}$ ). In the normal S- 126 cells

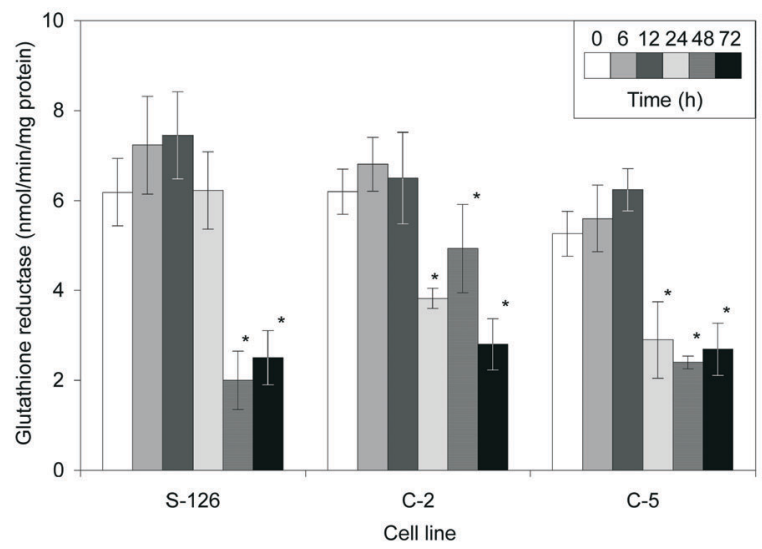

Figure 2. Effect of daunorubicin on glutathione reductase activity in diabetic (C-2 and C-5) and normal (S-126) fibroblasts.

Cells were processed as in the legend to Fig. 1. Data are expressed as the mean \pm S.D. of at least six independent determinations. ${ }^{*} P<0.05$ as compared with control (time zero for respective cells).

DNR also markedly lowered the reductase activity at 48 and $72 \mathrm{~h}$ after drug treatment, to $32.4 \%$ and $40.4 \%$ of control values at time 0 , respectively.

As shown in Fig. 3, DNR induced a progressive enhancement of GST activity in the diabetic cell lines (mean increase $70 \%$ at $72 \mathrm{~h}$ ). The GST activity in drug-treated normal cells was increased by $20-30 \%$ at $12-24 \mathrm{~h}$ and declined at $72 \mathrm{~h}$ after drug exposure.

\section{Morphology of drug-treated cells}

The morphological changes of the diabetic and normal cells induced by DNR exposure are presented in Fig. 4. The cultured cell lines were stained with Hoechst 33342 and analyzed by fluorescence microscopy. Hoechst 33342 is a dye that complexes with condensed DNA in apoptotic cells. Under the experimental conditions, cells treated with the drug showed the characteristic morphological hallmarks of apoptosis such as cell shrinkage, 
perinuclear clumping of condensed chromatin at $24 \mathrm{~h}$ and the presence of apoptotic bodies at $72 \mathrm{~h}$.

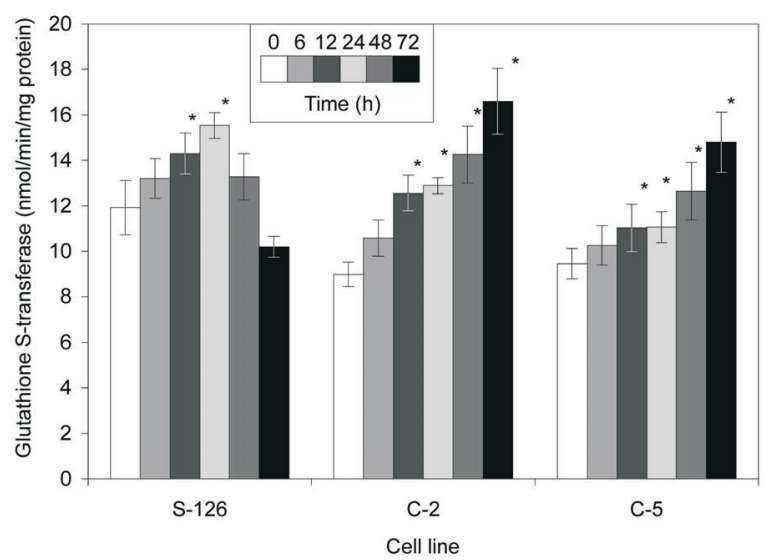

Figure 3. Effect of daunorubicin on glutathione $S$-transferase activity in diabetic (C-2 and C-5) and normal (S-126) fibroblasts.

Cells were processed as in the legend to Fig. 1. Data are expressed as the mean \pm S.D. of at least six independent determinations. ${ }^{*} P<0.05$ as compared with control (time zero for respective cells).

\section{DISCUSSION}

In the present study we have examined the role of the GSH-antioxidant system in the protection of cultured diabetic human fibroblasts against oxidative stress. We first compared the level of glutathione and GSH-related enzymes in untreated (control) normal and diabetic cells. These findings indicated a significantly elevated activity of total glutathione peroxidase and decreased activity of glutathione $S$-transferase in diabetic fibroblasts (cell lines C-2 and C-5) in comparison with normal cells (cell line S-126). The levels of GSH and glutathione reductase were similar in both types of cells. Furthermore, the ratio of GSH to total glutathione was also comparable and amounted 0.9 and 1.0 in the diabetic and normal cells, respectively. Many studies have demonstrated similar levels of glutathione in diabetic patients and healthy population (Di Simplico et al., 1995; Srivastava et al., 1989). However, there are also papers noting a lower glutathione content in patients with diabetes mellitus than in control group (Mukherjee et al., 1998; Thornalley et al., 1996).

At present, there is no data concerning the role of glutathione and GSH-dependent enzymes in diabetic patients exposed to anticancer drugs. Using the cultured diabetic cells we showed that daunorubicin induced in these cells considerable changes in the glutathione homeostasis. The drug caused a time-dependent decrease of GSH and glutathione reductase levels and reduction of the ratio of GSH to total glutathione. At the same time a significant increase in the activity of total, Se-dependent as well as Se-independent glutathione peroxidase and glutathione transferase was observed. Our results suggest that a loss of GSH in drug-treated diabetic cells may be due both to greater detoxification activity and lower efficacy in the reduction of GSSG.

Many reports have demonstrated in the last few years that anthracycline drugs decrease GSH content in different cells. A decreased level of GSH was observed in cultured heart cells exposed to doxorubicin treatment (Julicher et al., 1985; Olson et al., 1980; Paranka \& Dorr, 1994) and in trisomic human fibroblasts following exposure to DNR (Zatorska \& Jóźwiak, 2002). Under oxidative stress conditions, changes in glutathione levels may be associated with a number of processes such as free radical scavenging, reduction of peroxides and detoxification of electrophilic agents to less toxic compounds (Meister, 1995; Palmer \& Paulson, 1997; Bladeren, 2000). Based on our results, DNR-treated diabetic cells were unable to maintain stable GSH content as well as the ratio of GSH to total glutathione. Moreover, the reduced GSH content and a concomitant decrease of glutathione reductase activity suggest that the reductive capacity of the cells was insufficient to protect them against GSSG formation. Simultaneously, the drug significantly enhanced the Se-dependent and Se-independent peroxidase $\left(\mathrm{GPX}_{\mathrm{x}}\right)$ and GST activities. These enzymes play a crucial role in GSH-mediated de- 

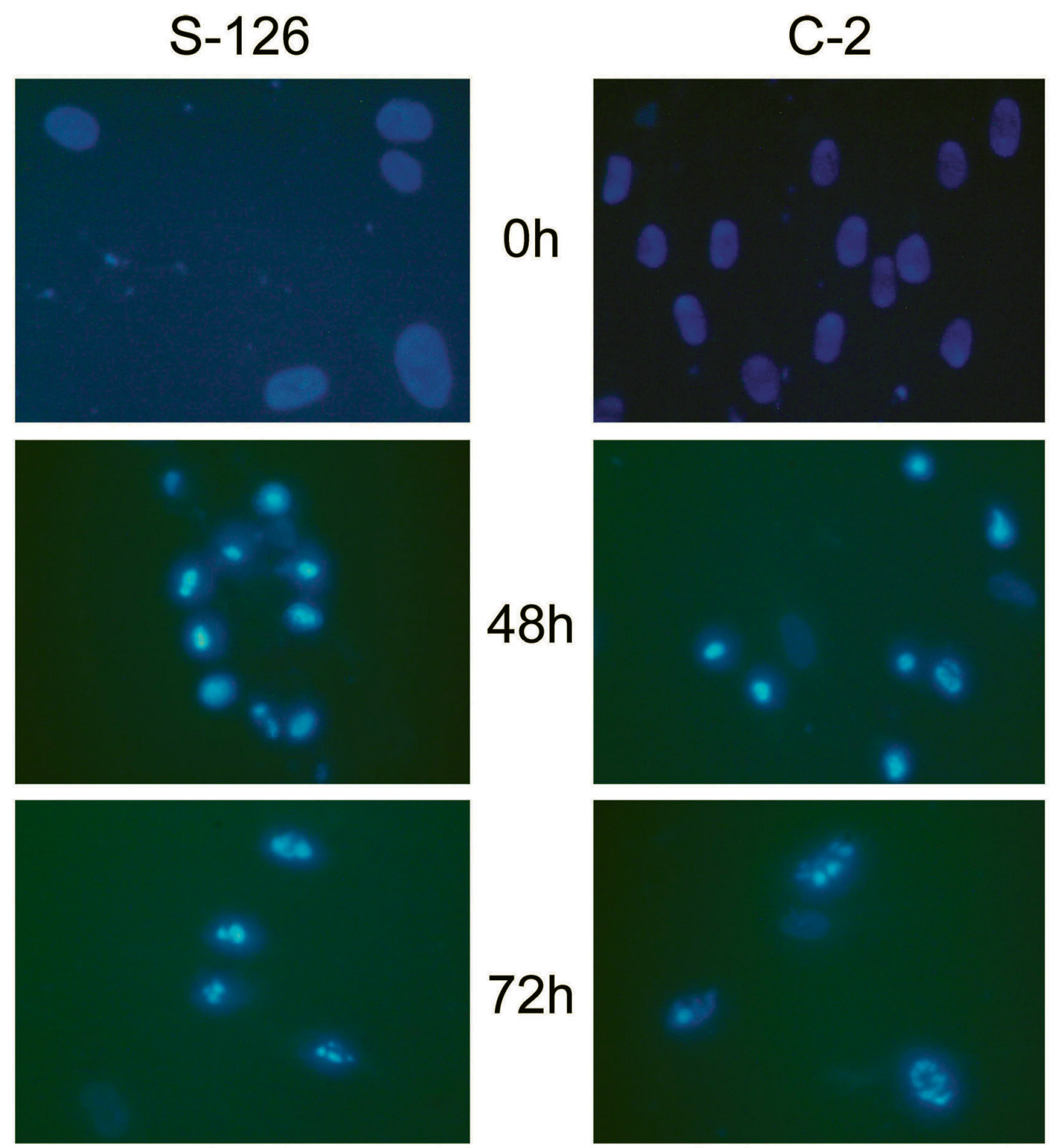

Figure 4. Morphological changes in daunorubicin treated diabetic (C-2) and normal (S-126) fibroblasts.

Cells were treated with $4 \mu \mathrm{M}$ DNR for $2 \mathrm{~h}$ and cultured in drug-free medium for 48 and $72 \mathrm{~h}$. Control $(0 \mathrm{~h})$ and drug-treated cells were stained with Hoechst 33342, transferred onto glass slides, representative areas were photographed under an Olympus fluorescence microscope equipped with a NU filter using a $400 \times$ magnification.

fense mechanisms against ROS and oxidative stress-induced cellular damage (Cnubben et al., 2001; Hayes \& McLellan, 1999; Tew, 1994). GPX $\mathrm{X}_{\mathrm{X}}$ are able to reduce endogenously produced $\mathrm{H}_{2} \mathrm{O}_{2}$ and organic hydroperoxides. GSH, as a substrate for GPX reactions also results in GSSG formation. The second enzyme GST exerts its protective functions utilizing GSH by two main mechanisms. The enzyme catalyzes the conjugation of GSH with various electrophilic compounds, including anthracycline antibiotics. GST also catalyzes a pero- xidative reaction with production of GSSG (Hayes \& McLellan, 1999; Tew, 1994). The ability of GST to alter the level of intracellular glutathione in response to generation of ROS has been implicated in protection of cells against free-radical inducing agents (Baez et $a l ., 1997$; Tew \& Ronai, 1999). An increase in GST activity has been reported in cultured heart cells and trisomic fibroblasts following exposure to anthracycline drugs (Julicher et al., 1985; Paranka \& Dorr, 1994; Zatorska \& Jóźwiak, 2002). 
A major mechanism for the up and down regulation of the GSH-related enzymes in drug-treated diabetic cells is based on the ROS-mediated induction of oxidative stress. Recently, we have also examined the level of $\mathrm{H}_{2} \mathrm{O}_{2}$ in diabetic cells. The level of $\mathrm{H}_{2} \mathrm{O}_{2}$ in the C-2 cell line was increased by $40 \%$ in comparison with normal fibroblasts. In DNR-treated diabetic cells the $\mathrm{H}_{2} \mathrm{O}_{2}$ content increased at 6 $\mathrm{h}$ and slowly declined after $24-72 \mathrm{~h}$ of drug exposure to the respective control values at time 0 (unpublished data). These findings imply that ROS-mediated oxidative modifications of GSH-related enzymes may lead to changes in their activity which, in turn, cause a perturbation in the intracellular glutathione level. Further studies are needed to determine the exact regulatory mechanism of GSH-dependent enzymes in cells exposed to anticancer drugs treatment.

The cellular GSH-redox status is also an important factor during apoptosis mediated by endogenous ROS (Tan et al., 1998; Zucker et al., 1997). Reduction of the intracellular GSH content has been shown to induce apoptosis in cultured mouse $\mathrm{MxC} 11$ and $\mathrm{C} 3 \mathrm{H}$ 10T1/2 fibroblasts (Zucker et al., 1997), human B lymphoma and T cells (Amstrong et al., 2002; Chiba et al., 1996) and cultured neurons (Ahlemeyer \& Krieglstein, 2000; Ratan et al., 1994). The findings reported by Armstrong et al. (2002) suggest that GSH depletion can act as a potent early activator of apoptotic signaling. Recently, a relation between the extent of apoptosis and intracellular glutathione concentrations has been shown in cultured human neuroblastoma SK-N-SH cells (Shimizu et al., 2002). Our results, obtained by simultaneous microscopy analysis, indicated that DNR treatment induced changes in morphology of the nucleus in diabetic cells. The occurrence of condensed chromatin and apoptotic bodies was accompanied by a decrease of GSH content.

A comparison of the GSH-antioxidant system in diabetic cells and normal fibroblasts exposed to the drug revealed that a given DNR concentration induced similar alterations in the GSH content and the ratio of GSH to total glutathione. Substantial differences between the two types of cells were observed in GST and Se-dependent glutathione peroxidase activities. In drug-treated normal cells, a smaller increase of the GST and a significantly higher enhancement of Se-dependent peroxidase activities were noted than in diabetic fibroblasts. The differences in the response of diabetic and normal fibroblasts may result from different sensitivity of the cells to DNR treatment as well as from different cellular antioxidant capacity.

In summary, our results indicate that daunorubicin induces in cultured normal and diabetic fibroblasts significant changes in the GSH antioxidant system. We suggest that drug-induced oxidative stress in the cells is tightly connected with the disturbances both in the enzymatic and non-enzymatic antioxidant defenses. Under oxidative stress, GSH depletion may play an important role in the apoptotic process of diabetic cells.

\section{R E F E R E N C E S}

Ahlemeyer B, Krieglstein J. (2000) Inhibition of glutathione depletion by retinoic acid and tocopherol protects cultured neurons from staurosporine-induced oxidative stress and apoptosis. Neurochem J.; 36: 1-5.

Akerboom TP, Sies H. (1981) Assay of glutathione, glutathione disulfide and glutathione mixed disulfides in biological samples. Meth Enzymol.; 77: 373-82.

Armstrong JS, Steinauer KK, Hornung B, Irish JM, Lecane P, Birrell GW, Peehl DM, Knox SJ. (2002) Role of glutathione depletion and reactive oxygen species generation in apoptotic signaling in a human B lymphoma cell line. Cell Death Differ.; 9: 252-63.

Baez S, Segura-Aguilar J, Widersten M, Johnson AS, Mannervik B. (1997) Glutathione transferases catalyse the detoxification of oxidized metabolites (o-quinones) of catecholamines and may serve as an antioxidant sys- 
tem preventing degenerative cellular processes. Biochem J.; 324: 25-8.

Bladeren van PJ. (2000) Glutathione conjugation as a bioactivation reaction. Chem Biol Interact.; 129: 61-76.

Carlberg J, Mannervik B. (1975) Purification and characterization of flavoenzyme glutathione reductase from rat liver. $J$ Biol Chem.; 250: 5475-80.

Chiba T, Takahashi S, Sato N, Ishii S, Kikuchi K. (1996) Fas-mediated apoptosis is modulated by intracellular glutathione in human $\mathrm{T}$ cells. Eur J Immunol.; 26: 1164-9.

Cnubben NH, Rietjens JM, Wortelboer H, van Zanden J, van Bladeren PJ. (2001) The interplay of glutathione-related processes in antioxidant defense. Environ Toxicol Pharmacol.; 10: $141-52$.

Di Simplicio P, de Giorgio LA, Cardaioli E, Lecis R, Miceli M, Rossi R, Anichini R, Mian M, Seghieri G, Franconi F. (1995) Glutathione, glutathione utilizing enzymes and thioltransferase in platelets of insulin-dependent diabetic patients: relation with platelet aggregation and with microangiopatic complications. Eur J Clin Invest.; 25: 665-9.

Gewirtz DA. (1999) A critical evaluation of the mechanisms of action proposed for the antitumor effects of the anthracycline antibiotics adriamycin and daunorubicin. Biochem Pharmacol.; 57: 727-41.

Griffith OW. (1999) Biological and pharmacological regulation of mammalian glutathione synthesis. Free Radic Biol Med.; 27: 922-35.

Hammond CL, Lee TK, Ballatori N. (2001) Novel roles for glutathione in gene expression, cell death, and membrane transport of organic solutes. J Hepatol.; 34: 946-54.

Hayes JD, McLellan JJ. (1999) Glutathione and glutathione-dependent enzymes represent a coordinately regulated defence against oxidative stress. Free Radic Res.; 31: 273-300.

Julicher RH, van der Laarse A, Stevrenberg L, Bloys van Treslong CH, Bast A, Noordhoek J. (1985) The involvement of an oxidative mechanism in the adriamycin-induced toxicity in neonatal rat heart cell cultures. Res Commun Chem Pathol Pharmacol.; 47: 35-47.

Lowry OH, Rosebrough NJ, Farr AL, Randal RJ. (1951) Protein measurement with the Folin phenol reagent. J Biol Chem.; 193: $265-75$.

Meister A. (1995) Glutathione metabolism. Meth Enzymol.; 251: 3-7.

Mukherjee B, Anbazhagan S, Roy A, Ghosh R, Chatterjee M. (1998) Novel implications of the potential role of selenium on antioxidant status in streptozotocin-induced diabetic mice. Biomed Pharmacother.; 52: 89-95.

Meyers C, Mimnaugh EC, Jeh GC, Sinha BK. (1988) Biochemical mechanisms of tumor cell kill by anthracyclines. In: Anthracycline and anthracenedione-based anticancer drugs. Lown W. ed, pp 527-69. Elsevier, Amsterdam.

O’Brien PJ. (1991) Molecular mechanisms of quinone cytotoxicity. Chem-Biol Interact.; 80: 1-41.

Olson RD, MacDonald JS, van Boxtel CJ, Boerth RC, Harbison RD, Slonim AE, Freeman RW, Oates JA. (1980) Regulatory role of GSH and soluble sulfhydryl groups in the toxicity of adriamycin. $J$ Pharmacol Exper Ther.; 215: 450-4.

Palmer HJ, Paulson KE. (1997) Reactive oxygen species and antioxidants in signal transduction and gene expression. Nutr Rev.; 55: $353-61$.

Paranka NS, Dorr RT. (1994) Effect of doxorubicin on glutathione and glutathione-dependent enzymes in cultured rat heart cells. Anticancer Res.; 14: 2047-52.

Powis G. (1989) Free radical formation by antitumor quinones. Free Radic Biol Med.; 6: 63-101.

Przybylska M, Koceva-Chyła A, Rózga B, Jóźwiak Z. (2001) Cytotoxicity of daunorubicin in trisomic $(+21)$ human fibroblasts: relation to drug uptake and cell membrane fluidity. Cell Biol Int.; 25: 157-70.

Ratan RR, Murphy TM, Baraban JM. (1994) Oxidative stress induces apoptosis in embryonic cortical neurons. J Neurochem.; 62: 376-9. 
Rice-Evans CA, Diplock AT, Symons MC. (1991) Techniques in free radical research. Elsevier, Amsterdam.

Samiec PS, Drews-Botsch C, Flagg EW, Kurtz JC, Sternberg P Jr, Reed RL, Jones DP. (1998) Glutathione in human plasma. Decline in association with aging age-related macular degeneration and diabetes. Free Radic Biol Med.; 24: 699-704.

Shimizu E, Hashimoto K, Komatsu N, Jyo M. (2002) Roles of endogenous glutathione levels on 6-hydroxydopamine-induced apoptotic neuronal cell death in human neuroblastoma SK-N-SH cells. Neuropharmacology; 43: 434-43.

Sies H. (1999) Glutathione and its role in cellular functions. Free Radic Biol Med.; 27: 916-21.

Srivastava SK, Ansari NH, Liu S, Izban A, Das B, Szabo G, Bhatnagar A. (1989) The effect of oxidants on biomembranes and cellular metabolism. Mol Cell Biochem.; 91: 149-57.

Tan S, Sagara Y, Liu Y, Maher D, Schubert D. (1998) The regulation of reactive oxygen species production during programmed cell death. Cell Biol.; 141: 1423-32.
Tew KD. (1994) Glutathione-associated enzymes in anticancer drug resistance. Cancer Res.; 54: 4313-20.

Tew KD, Ronai Z. (1999) GST function in drug and stress response. Drug Resist Updat.; 2: 143-7.

Thornalley PJ, McLellan AC, Lo TW, Benn J, Sonksen PH. (1996) Negative association between erythrocytes reduced glutathione concentration and diabetic complications. Clin Sci.; 91: 575-82.

Wernerman J, Luo J-L, Hammarqvist F. (1999) Glutathione status in critically-ill patients: possibility of modulation by antioxidants. Proc Nutr Soc.; 58: 677-80.

Zatorska A, Jóźwiak Z. (2002) Involvement of glutathione and glutathione-related enzymes in the protection of normal and trisomic human fibroblasts against daunorubicin. Cell Biol Int.; 26: 383-91.

Zucker B, Hanusch J, Bauer G. (1997) Glutathione depletion in fibroblasts is the basis for apoptosis-induction by endogenous reactive oxygen species. Cell Death Differ.; 4 : 388-95. 